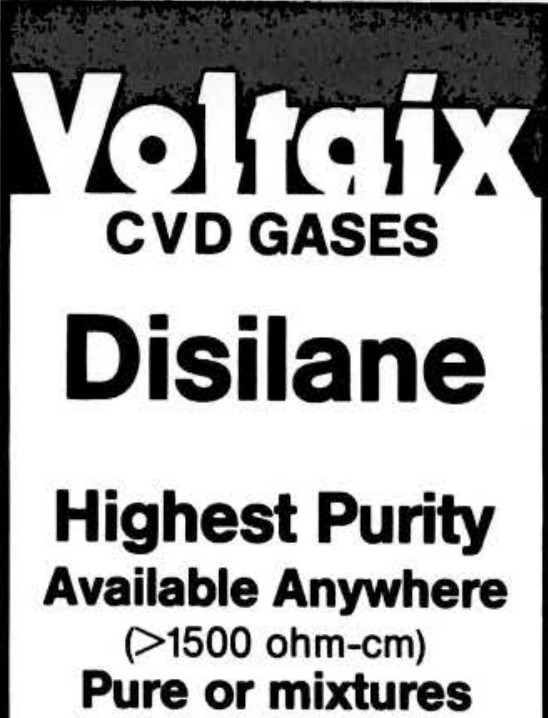

Quality Control

- $100 \%$ GC / MS analysis

Packaging Options

- Steel, polished steel or aluminum cylinders

- Pneumatic valves for fail-safe gas supply

- Choice of flow restrictor for added safety

- VCR outlets for UHV connection to system

Growing Applications

- Ge-Si alloys

- Polysilicon

- Low temperature epi

- BPSG, PSG, SG coatings

- High rate PECVD

\section{Now in Europe thru}

OTAVI MINEN AG

Telefon 061 96/70 28-0

Telex 4072630 otav

Telefax 702880

\section{Voltaix, Inc.}

P.O. Box 5357, 197 Meister Ave.

N. Branch, New Jersey 08876

Telephone: (201) 231-9060

Telex: 9102500134 VoltaixUQ

Please visit Booth No. 604 at the MAS

Show in San Diego, April 25-27

\section{DOE Notes}

\section{SSC Management and Operating} Contractor Selected

The U.S. Department of Energy has selected and signed a contract with Universities Research Association Inc. (URA) to be the management and operating contractor for the Ronald Reagan Center for High Energy Physics, which will build and operate the Superconducting Super Collider.

URA, a consortium of 66 universities, leads a team including two major private companies-Sverdrup Corporation and EG\&G Inc. Roy Schwitters, currently at the Harvard University physics department, will be the director of the new center to be located in Ellis County, Texas.

Sverdrup, headquartered in St. Louis, Missouri, designs, constructs and provides project management services for large-scale, advanced technical facilities. EG\&T Inc., of Wellesley, Massachusetts, is a diversified company providing advanced scientific and technical products and services to commercial and government customers.

URA will establish a laboratory organization to manage and administer the design, construction and commissioning of the SSC followed by an optional five-year term for an initial operating phase. URA will also assume responsibility for the SSC R\&D program.

Congress has not yet approved construction of the project, but has appropriated approximately $\$ 100$ million this fiscal year for R\&D, site selection, and preliminary engineering and design activities. The total estimated cost of the project is $\$ 4.4$ billion in fiscal year 1988 dollars. This work would include design and construction of conventional facilities, magnet fabrication, fabrication of other technical components and provisions of other materials and equipment.

A large portion of the project work will likely be performed by additional subcontractors competitively selected from private industry. URA will select an architectengineer/construction manager, which will in turn do the detailed design and engineering and subcontract for construction of the project's tunnel and buildings. This effort, including the money paid to construction subcontractors, is expected to cost approximately $\$ 1$ billion.

\section{NSF Notes}

\section{SBIR Program Awards \$8.2 Million}

Cutting-edge, high-risk, high-payoff research is the potential result of $\$ 8.2$ million in grants made by the National Science Foundation's Small Business Innovation Research (SBIR) program.

This year's grantees, 149 small high tech- nology firms, are located in $\mathbf{2 8}$ states, and range in size from one to $\mathbf{4 0 0}$ employees. Under Phase I of the three-phase SBIR program, NSF awarded up to $\$ 50,000$ to each company. Approximately two-thirds of the awards are for projects involving materials characterization, processing, synthesis, and engineering.

Among the firms that have developed new products and processes with such grants are Charles Evans \& Associates, Inc. of Redwood City, California, and Radiation Monitoring Devices, Inc. of Watertown, Massachusetts. Charles Evans \& Associates has marketed its advanced imaging detector system for ion microscopy instruments. Sales now exceed $\$ 5$ million, and $60 \%$ of the instruments are exported. Customers include IBM, AT\&T, Xerox, Toshiba, British Telecom, and Nippon Telephone and Telegraph.

Radiation Monitoring Devices has introduced an analyzer critical to productionline quality control for glass reinforced plastics produced in billion dollar quantities, such as automobile body panels and computer cases and telephones. Sales exceeding \$1 million include customers such as General Electric, Ford, Du Pont, Bayer, and Ciba-Geigy.

Abstracts of the 1988 SBIR Phase I awards and copies of the 1989 solicitation can be obtained from the National Science Foundation, Forms and Publications Office, 1800 G Street NW, Room 232, Washington, DC 20550.

\section{NATO Countries to Host \\ 54 NSF Fellows}

NSF-NATO Postdoctoral Fellowships in Science were recently awarded to 54 young U.S. scientists and engineers for full-time postgraduate study abroad at institutions and laboratories in NATO countries.

This year NATO funds were again supplemented by contributions from the NSF research directorates, allowing an increased number of recipients in physics and engineering. Of the awards announced, 22 were for research and training in the life sciences; 30 in the physical sciences, mathematics, and engineering; and 2 in the social and behavioral sciences.

This year's NSF-NATO Fellows will be affiliated with institutions in nine other NATO countries, with the majority traveling to the United Kingdom, France, and the Federal Republic of Germany. Recipients represent 22 states and Puerto Rico; 15 women are among the grantees.

For information about NSF-NATO Postdoctoral Fellowships, contact: NATO Postdoctoral Fellowships Program, 1800 G Street NW, Washington, DC; telephone (202) $357-9466$. 